1953, there are thirty-one essays divided into three major sections, ( 1 ) bibliography and the theory of knowledge, (2) library administration and techniques and (3) the history of books and libraries. The most prominent librarians in all the Germanies have joined in giving homage to Vorstius, and the contributors include such well known names as Georg Leyh, Donker Duyvis, and Ilse Schunke.

It would be difficult to do full justice to all the important essays that have been printed in this volume. The fact that the book was edited in East Germany for an East German has brought such essays as one by Todor Borov, director of the Bulgarian Bibliographical Institute, on the primary national bibliography of Bulgaria, František Horák, director of the Ceskoslovenska Akademie Věd. Základni Knihovna in Prague, on the library of the Czech Academy of Sciences, and Othmar Feyl, librarian of the University of Jena, on the classification scheme for the bibliographies of the book chambers of the U.S.S.R. Leyh's little essay entitled "Bibliographisches" is another useful contribution to library history. Fritz Redenbacher's study of the building problems of the University of Erlangen Library is instructive for any librarian who wrestles with spatial issues. Ilse Schunke's notes on library history in Dresden are based on her study of bindings. Willi Gober, director of the old University of Berlin Library (to be distinguished from the new Free University Library), reviews the old problems of centralization versus decentralization, showing a strong tendency to the former in the present day. Hugo Alker reviews the history of subject cataloging in the University of $\mathrm{Vi}$ enna Library for the past two centuries. Donker Duyvis writes on the international significance of the Index Bibliographicus.

\section{FOLKWAYS RECORIDS}

World's leading producer of AUTHENTTC folk music on RECORDS, including THE ETHNIC FOIKWAYS LIBRARY which contains an unusual selection of the music of over 200 peoples, recorded on location by native orchestras and vocal groups; each Long Play Record is accompanied by extensive notes by famous collectors and recognized authorities

And the famous SONGS TO GROW oN series for chtldren ANTHOLOGY OF JAZZ and AMEIRICAN FOLK MUSI
series.

Most of the issues are original recordings on HIGH FIDELITY - 40-18,000 cycles. ALL FOLKWAYS RTCORDS are guaranteed for quality of reproduction and content.

For complete catalog write to:

FOLKWAYS RECORDS \& SERVICE CORP. 117 West 46th St., New York 36, N. Y.
These are but a few samples of a rich and instructive volume, well worthy of a librarian such as Vorstius, who himself has contributed so much to library literature. Unlike some homage volumes, this one is intelligently planned and executed, and its value is enhanced by an index of names and places. In every sense the Vorstius Festschrift is a significant contribution to librarianship.-Lawrence S. Thompson, University of Kentucky Library.

\section{Economical Cataloging:} A Reply

In the article "How Little Cataloging Can Be Effective" (c\&RL, April, I954), Mr. Wyllis Wright states that author dates shall not be recorded except to distinguish between authors of the same name represented in the catalog. It seems to me that it adds to the understanding of a book to know at what period of an author's lifetime a particular book was written. Only author dates in relation to the date of publication can tell whether a book was an early work, or written at the prime of the author's life, or shortly before his death.

A further simplification suggested by $\mathrm{Mr}$. Wright is to omit all translator notes, except on cards for those standard authors where a variety of translations may be expected. I feel as long as we trace and give credit to editors, joint editors, compilers, etc., we should trace for translators, too. In my opinion, translators make a greater contribution to a book than editors. To translate requires not only a strict conformity to the original text, it means also to recreate the original movement of thought, and in case of the translation of poetry, to recast the rhythm and rhyme inherent in the original line of the poem.

As to the omission of editor notes, one may be of the opinion that one person's use of the editor information (e.g. a candidate for a $\mathrm{Ph} . \mathrm{D}$. degree using this item) may make up for its lack of use by other students.

It seems to be very difficult to establish a criterion of usefulness of the cataloged information, because the use of the items on the catalog card is a value difficult to estimate in terms of figures and percentages. $-L u c y$ Selig, Cataloger, Dayton (O.) Public Library. 